\title{
Korkeakoulujen opiskelijavalintauudistus ja aikuisopiskelijan opiskelumahdollisuudet
}

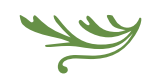

\begin{abstract}
Panosten reiluuden näkökulmasta korkeakoulutukseen pääsyn avoimuus eri-ikäisille on yhteiskunnallisesti tärkeä asia, sillä sisäänpääsymahdollisuudet

pitävät yllä koulutusjärjestelmän oikeudenmukaisuutta. 2010-luvulla toteutettu opiskelijavalintauudistus asettaa kuitenkin tutkintokoulutukseen pyrkivät aikuiset korkeakoulutuksen marginaaliin.
\end{abstract}

\section{$\mathbf{y}$} KORKEAKOULUJEN OPISKELIJAVALINTOJA on uudistettu koko 2010-luvun ajan. Uudistuksen päätavoitteeksi on määritetty toisen ja korkeaasteen välisen nivelvaiheen sujuvoittaminen ja nuorten ohjaaminen jatkamaan opintoja ilman välivuosia (esim. OPM 2010:11). Tehokkuutta ihannoivassa ajassa kannustetaan kouluttautumaan mahdollisimman nuorena ja nopeasti (Isopahkala-Bouret \& Siivonen 2016), eivätkä aikuisena aloitetut korkeakouluopinnot sovi tähän koulutusihanteeseen. Koulutuspoliittiseksi ongelmaksi määrittyy se, että korkeakouluopintojen aloitus pitkittyy mutta myös se, että korkeakoulututkinnon hankkineet palaavat suorittamaan uusia tutkintoja ja vievät näin opiskelupaikkoja nuoremmilta (Haltia 2012).
Miten opiskelijavalintojen uudistus kohtelee niitä hakijoita, jotka eivät ole niin kutsutussa nivelvaiheessa vaan pyrkimässä korkeakoulujen tutkintokoulutukseen vasta aikuisena? Millaisia vaikutuksia uudistuksella on heidän sisäänpääsymahdollisuuksiinsa? Jäljitämme artikkelissamme ensin opiskelijavalintauudistuksen vaiheita ja toimia, joilla uudistusta on viety käytäntöön. Tämän jälkeen kohdennamme analyysimme politiikkadokumenttien diskursiivisen luennan kautta siihen, miten aikuisuutta opiskelijavalintauudistuksessa käsitellään.

Päädymme tunnistamaan opiskelijavalintauudistuksesta kolme keskeistä koulutuspoliittista toimea, jotka kaikki, yhdessä ja erikseen, paikantavat opiskelemaan pyrkivät aikuiset korkeakoulujen tutkinto- 


\section{K OULUTUSJ̈̈RJESTELM $\ddot{A} \ddot{A}$}

\section{ON KEHITETTY TASA-}

\section{ARVOISUUDEN, \\ ELINIKÄISEN OPPIMISEN JA \\ "UMPIPERÄTTÖMYYDEN"}

IHANTEIDEN POHJALTA.

koulutuksessa marginaaliin ja märïttävät aikuisen aseman ei-oikeutetuksi suhteessa tutkinto-opiskeluun.

\section{AIKUISOPISKELIJAT JA KOULUTUKSELLISTEN MAHDOLLISUUKSIEN TASA-ARVO}

Suomalaiseen hyvinvointivaltiomalliin on katsottu kuuluvan mahdollisuus kouluttautumiseen missä tahansa elämänvaiheessa. Koulutusjärjestelmän kehittämistä ovat ohjanneet tasa-arvoisuuden, elinikäisen oppimisen ja "umpiperättömyyden" ihanteet (Antikainen 2006). Koulutuspolun eri vaiheissa on ollut mahdollista jatkaa yhdeltä koulutusasteelta seuraavalle ja siirtyä koulutussektorilta toiselle. Nuorena tehtyjä valintoja on pystynyt myöhemmin elämässä ainakin jossain määrin muuttamaan.

Niinpä aikuinen korkeakouluopiskelija ei Suomessa ole harvinaisuus. Koulutusjärjestelmä on sallinut opiskelun eri elämänvaiheissa, ja aikuisväestö suhtautuu elinikäiseen oppimiseen enimmäkseen myönteisesti (Olkinuora, Rinne, Mäkinen, Järvinen \& Jauhiainen 2008). Aikuiset voivat hakeutua tutkinto-opiskelijoiksi niin sanottujen päävalintojen kautta eli samoja hakureittejä pitkin kuin nuoret. Lisäksi aikuiset suosivat erilaisia maisterivalintoja ja avointen korkeakouluopintojen perusteella tehtäviä valintoja hakeutuessaan korkeakoulutukseen. (Rinne, Haltia, Nori \& Jauhiainen 2008.) Ne, joilla ei ole ylioppilastutkintoa, hakeutuvat yliopistoon tavallisesti ammatillisen toisen asteen koulutuksen ja ammattikorkeakoulun opinnot suoritettuaan, joten he ovat opintojen alkaessa usein muita opiskelijoita vanhempia (Haltia, Jauhiainen \& Isopahkala-Bouret 2017; 2018).
Suomessa yliopistojen tutkintokoulutuksessa ei ole erikseen aikuisopiskelijan statusta, vaan opiskelijat kuuluvat elämäntilanteestaan, iästään ja tavoitteistaan riippumatta samaan päätoimisten opiskelijoiden kategoriaan. Korkeakoulujen aikuiskoulutukseksi luetaan tutkintoon johtamaton maksullinen koulutus, jota ovat avoin korkeakouluopetus ja erilaiset täydennyskoulutuksen muodot (Moore 2011). Ammattikorkeakouluissa osa tutkintokoulutuksesta suunnataan osa-aikaisesti opiskeleville aikuisille, ja ylemmät ammattikorkeakoulututkinnot on säädöksin määritelty aikuiskoulutukseksi, johon pääsy edellyttää oman alan työkokemusta. (Ojala \& Haltia 2018; Kettunen, Pulkkinen \& Saari 2013.)

Tarkastelemme aikuisten mahdollisuuksia tutkintopainotteiseen korkeakouluopiskeluun ennen kaikkea tasa-arvon ja oikeudenmukaisuuden kysymyksenä. Onko uudistuksen tavoittelema opiskelijavalintajärjestelmä aikuisille reilu?

Korkeakoulutus koulutuksen ylimpänä asteena on Suomessa periaatteessa avoin kaikille. Korkeakoulukelpoisuus määritellään laajasti: kaikki toisen asteen tutkinnon suorittaneet ovat muodollisesti kelpoisia korkeakoulutukseen. Tutkintokoulutus on maksutonta, minkä ajatellaan tasaavan taustasta johtuvia eroja ja mahdollistavan opiskelun laajasti.

Korkeakoulutus on kuitenkin kilpailtua, eikä paikkoja riitä kaikille. Opiskelupaikkojen rajallinen saatavuus lisää niiden sosiaalista arvoa; koulutus on suhteellinen hyödyke (positional good; Brighouse \& Swift 2006) (esim. Aro 2014; Jacobs 2013). Korkeakoulutukseen pääsyn oikeudenmukaisuutta tarkasteltaessa onkin huomioitava eri hakijaryhmien välinen nollasummapeli. Kun yhden ryhmän koulutukselliset mahdollisuudet parantuvat, jonkin toisen ryhmän tilanne vastaavasti huononee, ellei koulutuspaikkojen kokonaismäärää samalla lisätä (ks. Brighouse \& Swift 2006).

Koulutusjärjestelmien oikeudenmukaisuutta tarkasteltaessa on ensinnäkin kiinnitettävä huomiota korkeakoulupaikkojen saatavuuteen (availability; McCowan 2016): onko niitä ylipäätään riittävästi, jotta järjestelmää voidaan pitää oikeudenmukaisena? Toiseksi järjestelmää pitää tarkastella siitä näkökulmasta, miten saavutettavia (accessibility; McCowan 2016) paikat ovat eri ryhmien näkökulmasta. Millä 


\section{SAMAT S̈̈̈̈NNÖT EIV ̈̈T}

\author{
AINA TEE PELIST $\ddot{A}$ \\ OIKEUDENMUKAISTA, JOS
}

\section{PELAAJILLA ON ERIARVOISET \\ LӒнтӧKOHDAT.}

perusteella opiskelijavalinnat tehdään, ja mitä valintaperusteet merkitsevät eri hakijoiden näkökulmasta? Suomessakin korkeakoulutukseen päätyvät muita herkemmin ne, joiden vanhemmat ovat kouluttautuneet pitkälle (Kivinen, Hedman \& Kaipainen 2012). Korkeammista sosioekonomisista taustoista tulevat eivät pelkästään hae korkeakoulutukseen muita useammin vaan myös onnistuvat valinnoissa ja saavat opiskelupaikan muita useammin (Nori 2011).

Kolmanneksi voidaan vielä tarkastella eroja esimerkiksi eri korkeakoulujen tai koulutusohjelmien tarjoamien mahdollisuuksien laadussa tai arvostuksessa, ja niiden merkitystä opiskelijoiden kannalta (horizontality; McCowan 2016). Vaikka erot suomalaisessa kontekstissa näyttäytyvätkin maltillisina, eri alat ja korkeakoulutuksen instituutiot ovat meilläkin jossain määrin eriytyneet opiskelijoiden taustan mukaan (Nori 2011; Isopahkala-Bouret ym. 2018).

Valtiotieteiden ja oikeustieteiden professori Lesley A. Jacobs (2013, 42-45) on jäsentänyt mahdollisuuksien tasa-arvoa (equal opportunities) kolmen ulottuvuuden - menettelyn, taustaan kytkeytyvän ja panosten reiluuden - näkökulmista. Menettelyn reiluus (procedural fairness) viittaa kilpailun sääntöihin: urheilukilpailun tapaan koulutuskilpailussakin on säännöt. Koulutukseen pääsy perustuu johonkin mitattavaan kriteeriin, kuten tutkintotodistuksiin tai valintakoemenestykseen. Valittua menettelyä ja sen oikeudenmukaisuutta voidaan siten perustella sillä, että kriteerit ovat kaikille samat.

Taustaa koskeva reiluus (background fairness) viittaa kysymykseen siitä, onko kilpailijoilla reilu pelikenttä eli onko heidän mahdollista reilulla tavalla asettua kilpailuun toistensa kanssa. Samat säännöt eivät välttämättä tarkoita sitä, että tilanne olisi oikeudenmukainen, jos kilpailijat tulevat pelikentälle eriarvoisista lähtökohdista. Esimerkiksi pääsykoe voi merkitä aivan eri asioita erilaisista sosiaalisista ja koulutuksellisista taustoista tuleville: jotkut hakijat voivat esimerkiksi parantaa mahdollisuuksiaan osallistumalla valmennuskursseille (ks. Kosunen, Haltia \& Jokila 2015). Todistusten käyttäminen valintaperusteena saattaa näyttää neutraalilta tavalta valita opiskelijat mutta voi kohdella eri tavoin erilaisen koulutuspolun valinneita.

Aikuiskoulutusmahdollisuuksilla on merkitystä etenkin tasa-arvon ulottuvuudella, jota Jacobs nimittää panosten reiluudeksi (stakes fairness). Mistä lopulta kamppaillaan ja mitkä ovat panokset? Mitä voitto tai häviö kilpailussa tarkoittavat? Panosten tasa-arvossa on kolme tekijää:

1. Kilpailuun sisältyvää riskiä tulisi rajoittaa niin, ettei se nouse liian korkeaksi.

2. On asetettava kohtuullinen raja sille, mitä ja miten paljon on tosiasiallisesti pelissä.

3. Pitää jotenkin rajata, miten yhdessä kilpailussa menestyminen tai häviäminen vaikuttaa toiseen kilpailutilanteeseen. Jos esimerkiksi vain yksi tietty koetilanne märïttäisi nuoren ihmisen elämän suunnan koko loppuiäksi, kilpailutilannetta koskeva riski kasvaisi liian suureksi. Epäonnistumisesta kertaluonteisessa kokeessa ei saisi muodostua kohtuutonta estettä myöhemmille valinnoille tai pyrkimyksille elämässä. (Jacobs 2013, 42-45.)

Korkeakoulujen opiskelijavalintapolitiikka ei ole politiikkaa vain siitä, miten korkeakoulut valitsevat parhaat opiskelijat ja miten hakijavirtoja ohjaillaan. Sillä on laajemmin seurauksia myös siihen, miten tasavertaisena ja oikeudenmukaisena yhteiskuntamme kansalaisille näyttäytyy. Luottamusyhteiskunnassa on tärkeää, että julkiset instituutiot koetaan oikeudenmukaisiksi (Kouvo 2014). Aikuisten opiskelumahdollisuudet eivät siten koske vain aikuisopiskelijoiden oikeuksia, vaan ne nostavat esiin kysymykset siitä, miten määrääviä ylipäätään ovat elämässä kerran tehdyt valinnat. Aikuisten opiskelumahdollisuudet luovat uskoa siihen, että yhteiskunnassa on mahdollisuus vaikuttaa omaan asemaan ja oman elämän suuntaan koko elämän ajan. 


\section{AINEISTO JA ANALYYSITAPA}

Näemme analyysimme kohteen eli suomalaisen koulutuspolitiikan käytännöllisenä ja diskursiivisena toimintana (vrt. Ball 1994). Sen analyysi käytännöllisenä toimintana tarkoittaa yhteiskunnallisen tahdonilmaisun syntymisen ja päätöksenteon prosessien näkyväksi tekemistä.

Politiikan tarkasteleminen diskursiivisena toimintana puolestaan painottaa politiikkatekstien ja niissä käytettyjen puhetapojen todellisuutta tuottavaa ja muokkaavaa vaikutusta. Tekstit selittävät, tulkitsevat ja perustelevat opiskelijavalintoja koskevia suuntalinjoja ja toimintasuunnitelmia. Esille pantujen tahdonilmausten lisäksi on tärkeää kysyä, millaisia vaiettuja tai piilossa olevia merkityksiä politiikkatekstien neutraaleina näyttäytyvien puhetapojen takana on. (Bacchi 2000, 50; Allan 2012.) Ei riitä, että analysoidaan sisältöjä, vaan lisäksi on kysyttävä, mitä tekstistä puuttuu ja mistä hiljaisuudet kertovat (Chouliariki \& Fairclough 1999). Opiskelijavalinnoista puhumisen tavat ovat kehys, jossa keskustellaan valintamekanismeista ja samalla määritetään sitä, millaisia opiskelijoita korkeakoulutukseen halutaan.

Varsinaiset tutkimuskysymykset ovat seuraavat:

1. Miten opiskelijavalintauudistus on edennyt ja millaisten toimenpiteiden avulla sitä on viety eteenpäin?

2. Millainen paikka aikuisopiskelijoille uudistuksen myötä suomalaisessa korkeakoulujärjestelmässä määrittyy?

Opiskelijavalintauudistuksen alku voidaan paikantaa 2010-luvun taitteeseen, jota seuranneilla kahdella vaalikaudella uudistuksia on toteutettu ja pantu toimeen. Tarkastelun aikajänne on siten 2010-luku, vaikka julkista keskustelua aiheesta on käyty eniten tämän vuosikymmenen loppupuolella, lähinnä suhteessa siihen, käytetäänkö valinnan kriteerinä ylioppilastutkintoa vai valintakoetta (Ahola \& Spoof 2018). Tutkimuksen aineisto koostuu keskeisistä opiskelijavalintauudistuksen yhteydessä tuotetuista politiikkadokumenteista: hallitusohjelmista ja niihin kytkeytyvistä suunnitelmista (Valtioneuvosto 2011, 2015;
2016:2, OKM 2012), kahdesta lakiesityksestä (HE 44/2012/vp; HE 244/2014/vp) ja kolmesta työryhmämietinnöstä (OPM 2010:11, OKM 2016:37; OKM 2017:25).1

Analyysin ensimmäisessä vaiheessa (tutkimuskysymys 1) luimme koulutuspoliittisia dokumentteja paikantamalla valintauudistuksen olennaisia vaiheita ja konkreettisia toimia, joilla uudistusta on kuljetettu eteenpäin. Analyysimme oli kuvailevaa ja kartoittavaa, ja sen tarkoituksena oli tunnistaa uudistuksen täytäntöönpanon kriittiset pisteet, joihin kohdentaa tarkempi diskursiivinen luenta. Vaikka uudistus on ollut esillä julkisessa keskustelussa, siitä ei aiemmin ole tehty ajallisesti etenevää, analyyttista katsausta.

Analyysin toisessa vaiheessa (tutkimuskysymys 2) tutkimme tarkemmin opiskelijavalintauudistuksen poliittisia tekstejä. Kohdensimme katseemme ensimmäisessä analyysivaiheessa tunnistamiimme toimiin ja tarkastelimme korkeakoulutukseen pyrkivien aikuisten opiskelumahdollisuuksia niiden kautta. Analysoimme, miten politiikkadokumenteissa diskursiivisesti luodaan kategorioita, joihin eri-ikäisiä hakijoita asemoidaan. Diskursiivinen analyysi ohjasi meitä kiinnittämään kriittistä huomiota kielenkäyttöön, sanavalintoihin, kielikuviin ja asiayhteyksiin, joilla uudistusten pakottavuutta kehystettiin (Chouliariki \& Faicloug 1999). Analyysin osana tarkastelimme politiikkateksteille tyypillistä vakuuttelevaa ja suostuttelevaa retoriikkaa (vrt. Jokinen 1999).

\section{VALINTAUUDISTUKSEN KESKEISET TOIMET}

Korkeakoulujen opiskelijavalintojen uudistuksen lähtökohtana voidaan pitää koulutukseen siirtymistä ja tutkinnon suorittamista pohtineen työryhmän muistiota Ei paikoillanne, vaan valmiit, hep! (OPM 2010:11). Siinä kehystettiin opiskelijavalinnan ongelmat ennen kaikkea kahteen teemaan: hitaaseen siirtymään toiselta asteelta korkeakouluopintoihin ja moninkertaiseen korkeakoulututkintojen hankkimiseen. Jos paikkoja turvattaisiin mahdollisimman laajasti niille, jotka olivat tulossa korkeakoulutukseen ensimmäistä kertaa, hakijavirtoja ohjattaisiin paitsi tehokkaammin myös oikeudenmukaisemmin. (OPM 2010:11.) 
KAIKKIEN ALOITUSPAIKKOJEN

VARAAMISTA

ENSIKERTALAISILLE

ARVOSTELTIIN LAUSUNTO-

KIERROKSELLA RUNSAASTI.

Pääministeri Jyrki Kataisen (kok.) hallituksen ohjelmaan $(2011,34)$ kirjattiinkin tavoite sujuvoittaa korkeakouluopintoihin pääsyä ja varata päävalinnat "hakijoille, joilla ei ole aiempaa vastaavan tasoista tutkintoa tai opinto-oikeutta". Kehittämissuunnitelmassa (OKM 2012) paikkojen varaamiseksi kaavailtiin kaksivaiheista toteutustapaa:

”Ensimmäistä korkeakoulupaikkaa hakevien aseman parantamiseksi mahdollistetaan ensimmäisessä vaiheessa heidän valintansa omassa kiintiössään, jonka käyttöönotosta ja suuruudesta päättää korkeakoulu. Toisessa vaiheessa hakujärjestelmä uudistetaan siten, että yhteishaussa valitaan vain ensimmäistä korkeakoulupaikkaansa hakevia." (OKM 2012, 45.)

Uudistusten toteuttamiseksi lakia oli muutettava. Esitys lakimuutoksista annettiin eduskunnalle toukokuussa 2012, ja se sisälsi säädökset korkeakoulujen valtakunnallisesta yhteishausta ja sitä varten rakennettavasta sähköisestä hakujärjestelmästä sekä ensimmäistä paikkaansa hakevien kiintiöinnistä päävalinnassa omaksi ryhmäkseen. (HE 44/2012.)

Viimeistelyvaiheessa lakiesityksen perusteluihin kirjattiin, että kaavailuja toisesta vaiheesta ja kaikkien aloituspaikkojen varaamisesta ensikertalaisille oli lausuntokierroksella kritisoitu runsaasti. Uudistusta liudennettiinkin tältä osin, ja toisessa vaiheessa jätettiin voimaan linjaus, että yhteisvalinnan paikoista vain osa varattaisiin ensikertalaisille (HE 244/2014). Lakiesitysten perusteluissa rajattiin sitä, mitkä ryhmät kuuluisivat päävalintojen ja mitkä erillisvalintojen piiriin. Korkeakouluille jätettiin lopulta suuri valta päättää siitä, miten minkäkin ryhmän valintatapa järjestettäisiin ja miten suuriksi kiintiöt asetettaisiin (ks. HE 44/2012; HE 244/2014).

Kiintiöiden asettaminen tuli mahdolliseksi vuonna 2014, samalla kun korkeakoulujen yhteinen hakujärjestelmä, Opintopolku.fi-palvelu, otettiin käyttöön. Käytännössä korkeakoulut alkoivat kiintiöidä hakijoita vasta vuonna 2016, mikä oli takaraja kiintiön käyttöönotolle. Uudistustoimia oli siten käytännössä kaksi: 1) ensikertalaiskiintiöllä haluttiin suunnata paikkoja toivotuille hakijaryhmille, minkä 2) valtakunnallinen hakujärjestelmä teki mahdolliseksi.

Pääministeri Juha Sipilän (kesk.) hallitus aloitti työnsä vuonna 2015. Sen ohjelmaan kirjattiin tavoite korkeakoulujen valintamenettelyn uudistamisesta (Valtioneuvosto 2015, 18). Valtioneuvosto luopui perinteisestä hallitusohjelmaa täsmentävästä ja kokonaiskuvaa luovasta koulutuksen ja tutkimuksen kehittämissuunnitelmasta (Tervasmäki \& Tomperi 2018, 176), ja hallitusohjelman toimeenpanoa lähdettiin suuntaamaan niin kutsutuilla kärkihankkeilla. Siirtymisen nopeuttamiseksi toiselta asteelta korkeakouluihin toimintasuunnitelmaan kirjattiin seuraavaa:

"Opetus- ja kulttuuriministeriö käynnistää yhdessä korkeakoulujen kanssa prosessin, jossa korkeakoulut uudistavat valintamenettelyjään tavoitteena vähentää tarpeettomia välivuosia ja aikaistaa korkeakouluopintojen aloitusta. OKM ohjaa rahoituksella korkeakouluja luopumaan pitkäkestoisesta pääsykokeisiin valmistautumisesta, jolloin tarve osallistua valmennuskursseille vähenee oleellisesti. Ylioppilastutkintolautakunta ja korkeakoulut laativat toimenpideohjelman ylioppilastutkinnon paremmaksi hyödyntämiseksi valintamenettelyssä." (Valtioneuvosto 2016:2, 38.)

Ministeriö asetti työryhmän pohtimaan ylioppilastutkinnon parempaa hyödyntämistä valinnoissa. Loppuvuodesta 2016 antamassaan Valmiina valintoihin -raportissa työryhmä luonnosteli toimenpideohjelman. Sen päälinjaus oli, että korkeakoulujen tulisi tulevaisuudessa valita pääosa uusista opiskelijoista pelkän ylioppilastutkintotodistuksen 
Koulutuspolititisista

DOKUMENTEISTA VOIDAAN

\author{
LUKEA, MILLAINEN ON \\ OLETETTU OPISKELIJA,
} UUDISTUKSEN KOHDE.

perusteella. (OKM 2016:37.) Ammatillisten tutkintojen hyödyntämisestä valinnoissa käynnistettiin jatkotyö. Tehtävään asetettiin oma työryhmä, joka antoi Valmiina valintoihin II -mietintönsä keväällä 2017 (OKM 2017:25). Todistusvalintojen laajentamisen määräajaksi asetettiin vuosi 2020.

Analyysimme perusteella valintauudistus pantiin täytäntöön kolmella keskeisellä toimella:

1. valtakunnallisen hakujärjestelmän luominen (2014),

2. hakijoiden kiintiöinnit ja ensikertalaiskiintiön luominen (2016) sekä

3. valintakriteereiden muutos, toisin sanoen ylioppilastutkinnon voimakkaampi hyödyntäminen valinnoissa (2020).

Toimet asettuvat ajallisesti erilaisiksi vaiheiksi, jotka sekä seuraavat toisiaan että rakentuvat päällekkäisiksi ja toisiinsa nojaaviksi uudistuksen elementeiksi. Koulutuspoliittinen uudistus toteutetaan muuttamalla toimintaympäristöä, jossa korkeakoulujen opiskelijavalintoja tehdään.

\section{AIKUISTEN MARGINAALISEN ASEMAN RAKENTUMINEN OPISKELIJAVALINTOJEN UUDISTUKSESSA}

Uudistuksen toteutusta ohjanneeksi rationaliteetiksi on määrittynyt opiskelijavalinnan sujuvuuden ja tehostamisen edistäminen. Päätavoitteeksi on asetettu nuorten siirtymän nopeuttaminen toisen asteen ja korkea-asteen välisessä nivelvaiheessa. Koulutuspoliittisista dokumenteista voidaankin lukea, millainen on se "oletettu opiskelija" (implied student; Ulriksen 2009), jonka näkökulmasta uudistuksia tehdään.

\section{Valtakunnallisen hakujärjestelmän luominen}

Valtakunnallisen hakujärjestelmän luominen näyttäytyy teknisenä ja neutraalina tekijänä, ja sitä perustellaan ennen kaikkea valintojen selkeyttämisellä ja yksinkertaistamisella. Kun kaikki tapahtuu yhteisessä järjestelmässä, "[k] orkeakoulujen opiskelijahaun prosessit yhtenäistyvät ja virtaviivaistuvat" (HE 44/2012 vp, 28).

Opintopolku.fi-palvelua valintauudistuksessa voidaan pitää tärkeänä, sillä sen merkitys muotoutuu valintojen järkeistämisen ja standardisoinnin välineeksi. Muuttamalla järjestelmiä, joissa haut toteutetaan, tulee mahdolliseksi itse hakuprosessien muuttaminen. Järjestelmän tehtäväksi määrittyy tunnistaa erilaiset hakijat ja ohjata heidät prosessissa oikeaan paikkaan:

"Korkeakouluopiskelijoissa on iältään, tavoitteiltaan ja toiveiltaan eri tavoin profiloituneita opiskelijoita, joille tulisi löytää oikeat kanavat hakeutua koulutukseen ja suorittaa opintoja. Tällä hetkellä eräillä aloilla yliopistojen maisteriopintoja käytetään sekä perustutkintona että ammatillisena jatkokoulutuksena. Kun aikuisten koulutuskysyntä suuntautuu perusopintoihin, osa ensi kertaa opiskelemaan pyrkiville osoitetusta koulutuskapasiteetista ohjautuu todellisuudessa aikuisille." (OKM 2012,21.)

Yllä oleva esimerkki on aineistossamme yksi harvoja kohtia, joissa erityisesti mainitaan aikuiset, ja samalla eksplisiittisesti nimetään heidät ongelmalliseksi ryhmäksi. "Ensi kertaa opiskelemaan pyrkivät" ja "aikuiset" asetetaan vastakkain ja todetaan heidän kilpailevan samoista opiskelupaikoista.

Esimerkistä näkyy myös se, miten politiikkateksteissä määritetään aikuisen opiskelumotiiveja. Aikuisen opiskelua merkityksellistetään " ammatillisen jatkokoulutuksen" hankkimiseksi. Näin piirretään kuvaa aikuisesta, joka on jo suorittanut tutkinnon ja käyttää tutkintokoulutusta nyt ikään kuin väärin. Tämän rationaliteetin mukaista on ohjata aikuisten koulutuskysyntää pois tutkintokoulutuksesta, ja dokumentit puhuvatkin vaihtoehtojen tarjoamisesta korkeakoulututkinnon jo suorittaneille. Vaikka tutkintoon 


\section{TUTKINNON SUORITTANEET KÄYT $\ddot{A N N O ̈ S S A ̈ ~ S I V U U T E T A A N ~}$} POLITIIKKADOKUMENTEISSA.

johtamaton aikuiskoulutus ei sinänsä kuulu opiskelijavalintojen uudistukseen, se sidotaan politiikkadokumenteissa tähän tematiikkaan:

"Parannetaan korkeasti koulutettujen täydennyskoulutusmahdollisuuksia. Kannustetaan yliopistoja ja ammattikorkeakouluja tarjoamaan aikuiskoulutuksessa laajoja osaamiskokonaisuuksia, osia tutkinnoista ja muuta tutkintoja lyhytkestoisempaa koulutusta, myös tutkintoon johtavaa koulutusta hyödyntäen." (Kataisen hallitusohjelma 2012,35.)

Hakujärjestelmälle annetaan teksteissä rooli mahdollisten hakijoiden tavoitteiden suuntaajana. Jotta aikuisia saadaan ohjattua heille sopivaksi katsotuille uomille, järjestelmän kautta heille voidaan tarjota muuta kuin tutkintokoulutusta:

"Tutkintoon johtavan koulutuksen yhteishaun ohella tarjotaan korkeakouluille ja muille koulutuksen järjestäjille mahdollisuus esittää myös muu koulutustarjonta samassa keskitetyssä verkkopalvelussa. Osaamisen päivittämiseen ja elinikäiseen oppimiseen tarkoitettujen tutkintoon johtavan koulutuksen ulkopuolisten mahdollisuuksien tehokkaampi tarjoaminen vähentää yhteishaussa opiskelupaikoista kilpailevien joukkoa." (HE 44/2012, 29.)

Opintopolku.fi-palvelussa onkin esillä esimerkiksi avoimen yliopiston opintoja ja muita tutkintokoulutuksen vaihtoehtoja. Se on instrumentti, joka vaikuttaa olennaisesti siihen, millaisia valinnanmahdollisuuksia koulutusvaihtoehdoista kiinnostuneille avautuu. Kontrolloimalla hakijoiden saamaa tietoa heitä voidaan ohjata oikeaan suuntaan ja saada heidät näin pehmein keinoin tekemään toivotun kaltaisia valintoja.

\section{Hakijoiden kiintiöinnit ja ensikertalaiskiintiön luominen}

Standardoitu valtakunnallinen hakujärjestelmä helpottaa tutkintokoulutukseen hakevien järjestämistä jonoihin, kiintiöihin ja kategorioihin. Hakijoiden ryhmittely olikin toinen keskeinen politiikan toimi, jonka opiskelijavalintauudistuksesta tunnistimme. Kiintiöinnin kannalta olennaisena näyttäytyy toisen ja kolmannen asteen välisessä nivelvaiheessa olevien hakijoiden tunnistaminen. Aiemmissa yrityksissä nopeuttaa nivelvaihetta on eksplisiittisesti puhuttu 'uusista ylioppilaista' (esim. Ahola 2004). Uusi ylioppilas on implisiittisesti iältään nuori, vaikka toki osa ylioppilastutkinnoista tehdään vasta vanhemmalla iällä aikuislukiossa.

Vuoden 2012 lakiesityksen perusteluissa puhutaan samoin aluksi 'uusista, vastavalmistuneista ylioppilaista'. Tekstissä kuitenkin päädytään nopeasti käyttämään 'ensimmäistä korkeakoulupaikkaansa hakevan' käsitettä, mitä perustellaan yhdenvertaisuudella.

"Korkeakoulujen aloituspaikkojen varaaminen ensimmäistä korkeakoulututkintoon johtavaa opiskelupaikkaa hakeville nopeuttaa korkeakouluopintoihin sijoittumista. Aikaisemmin korkeakouluopintoihin sijoittumista on pyritty nopeuttamaan muun muassa vastavalmistuneille ylioppilaille annettavilla lisäpisteillä, mikä on kohdistunut vain tiettyyn toisen asteen koulutuksen päättäneiden joukkoon. Uudistuksen myötä korkeakouluopintoihin sijoittumista nopeutetaan tehokkaammin toimenpiteillä, jotka kohdistuvat kaikkiin ensimmäistä korkeakoulupaikkaansa hakeviin, eivätkä siten ole ongelmallisia yhdenvertaisen kohtelun vaatimuksen näkökulmasta." (HE 44/2012, 29-30)

Ensikertalaisen määre kattaa nuorten lisäksi ensimmäistä korkeakoulupaikkaansa hakevat aikuiset. Dokumenttien luenta kuitenkin paljastaa, miten 'ensikertalaisuus' edelleen kehystetään nuoruuteen liittyvillä tekijöillä. Sen yhteydessä puhutaan nimenomaan nivelvaiheesta ja nopeasta siirtymisestä koulutuksen seuraavalle asteelle, jolloin esimerkiksi aikuiset, jo työelämässä olleet, rajautuvat määrittelyiden ulkopuolelle. 
Tavoitteena on, että kun ensikertalaiset tunnistetaan hakijoista, heitä voidaan opiskelijavalinnoissa kohdella eri tavoin kuin muita hakijoita. Ensikertalaiset on kuitenkin vain yksi teksteissä näkyvä opiskelijakategoria, sillä dokumenteissa nimetään muitakin hakijaryhmiä, joihin liitetään erilaisia ominaisuuksia.

Muiden kuin ensikertalaisten jaotteleminen erilaisiin ryhmiin muuttui vuosien 2012 ja 2014 lakiesitysten välillä. Ensimmäisessä vaiheessa ensikertalaisten lisäksi muiksi ryhmiksi määritettiin alanvaihtajat ja siirtyjät. 'Alanvaihtajista' puhuttiin henkilöinä, jotka olivat jo opiskelemassa tai suorittaneet tutkinnon eri alalta kuin jolle he olivat pyrkimässä. 'Siirtyjinä' taas tarkasteltiin niitä opiskelevia tai tutkinnon suorittaneita, jotka siirtyivät omalla alallaan toiseen koulutukseen. (HE 44/2012, 7.) Sekä siirtyjä että alanvaihtaja saattoi määritelmän perusteella olla myös aikuinen.

Lainvalmistelun toisessa vaiheessa aikuisuudelle annettu tila kuitenkin kaventui. Hakijaryhmiksi tunnistettiin ensikertalaisten lisäksi siirtyjät ja tutkinnon jo suorittaneet. 'Siirtyjiksi' luettiin ne opiskelemassa olevat, jotka halusivat vaihtaa koulutustaan, kun taas 'tutkinnon jo suorittaneet' tarkoitti niitä, jotka olivat valmistuneet koulutuksesta ja hakivat suorittamaan uutta tutkintoa. Esitetyt toimet valinnoissa kohdistuvat erityisesti siirtyjiin, joille katsottiin tarvittavan mahdollisuuksia joustaviin menettelyihin. Näitä perusteltiin umpiperien välttämisellä, mutta ennen kaikkea siirtyjienkin mahdollisuuksista puhuttiin ensikertalaisten näkökulmasta.

"Valintatapojen ja valintaperusteiden sekä ohjauksen kehittämisen lisäksi ensimmäistä korkeakoulupaikkaansa hakevien pääsyä korkeakouluihin voidaan edistää myös kehittämällä joustavia siirtymäjärjestelyjä korkeakoulujen sisällä ja välillä niille opiskelijoille, joilla on jo opiskelupaikka korkeakoulussa ja jotka opintojensa aikana haluavat siirtyä jatkamaan opintojaan aiempien opintosuoritustensa pohjalta toisessa koulutuksessa." (HE 44/2012, 21-22.)

Kuva siirtyjästä on siten kuva nuoresta opiskelijasta, joka on tehnyt alun perin värän valinnan ja haluaa korjata virheensä. Siirtymämahdollisuuksien olemassaolon oletetaan näin viestivän ensimmäistä paikkaansa hakeville, että kerran tehtyä valintaa voi vielä kesken opintojen muuttaa. Tutkinnon suorittaneet sen sijaan sivuutetaan politiikkadokumenteissa lähes kokonaan. Heihin viitattaessa puhutaan tutkintokoulutukselle vaihtoehtoisten mahdollisuuksien tarjoamisesta.

Kategorisointi rakentaa näin aikuisuuden position niin, että se voidaan rajata opiskelijavalintapolitiikassa tutkintokoulutuksen ulkopuolelle. Aikuisuus kirjoitetaan teksteissä ulos sekä ensikertalaisten että siirtyjien kategorioista. Se liitetään ainoastaan tutkinnon suorittaneiden positioon. Koulutuspolitiikan rationaliteettia voidaan oikeudenmukaisuuden näkökulmasta analysoida niin, että koska paikkojen saatavuus (availability) on rajallinen, on oikeutettua rajata aikuisten mahdollisuuksia (accessibility) ja ohjata heitä vähemmän haluttuun koulutukseen (horizontality) (ks. McCowan 2016).

\section{Valintakriteereiden muutos ja ylioppilastutkinnon voimakkaampi hyödyntäminen valinnoissa}

Valintakriteereiden muuttaminen tarkoitti käytännössä valintakokeiden merkityksen vähentämistä ja todistusvalintojen painoarvon kasvattamista. Politiikkadokumenttien luennassa paljastuu retorinen kaava, jossa valintakokeet ja todistusvalinta asetetaan toistensa vastakohdiksi (ks. Jokinen 1999, 153). Kokeet liitetään erilaisiin ongelmiin ja haittoihin, kun taas todistusvalintaan liitetään myönteisiä asioita. (OKM 2016:37, 9-10.)

Valintakokeita ongelmallistetaan dokumentissa monin tavoin. Niiden todetaan muun muassa hidastavan siirtymää ja muodostavan pullonkaulan korkeakoulujen porteille. (OKM 2016:37, 17,47). Pääsykokeiden syyksi luetaan sekin, että monet lähtevät opiskelemaan ulkomaille. Niiden todetaan lisäksi mahdollistavan hakumahdollisuuksia eriarvoistavat valmennuskurssit. (OKM 2016:37, 30-31.)

Ongelmatilanteen ratkaisuksi työryhmä tarjoaa valintojen tekemistä ylioppilastutkinnon arvosanojen perusteella. Tekstissä argumentoidaan sen puolesta, miksi ylioppilastutkinnon arvosanojen 
Motivaation

YHTEYDESSÄ PUHUTAAN

AVOIMESTI NUORISTA

KORKEAKOULUTUKSEEN

HAKIJOISTA.

käyttäminen olisi ylivertainen ratkaisu valintakokeisiin verrattuna. Ylioppilastutkinnon käyttämistä perustellaan muun muassa sillä, että joissakin valintakokeissa mitataan aivan samoja asioita kuin ylioppilastutkinnossa. Ylioppilaskoe näyttäytyy tekstissä neutraalina valintakriteerinä, joka menettelyn tasa-arvon (Jacobs 2013, 42-45) mukaisesti kohtelee hakijoita samalla tavalla:

"Ylioppilastutkinto alueellisesti kattavasti järjestettyine kokeineen ja yhdenmukaisine arvostelujärjestelmineen on tasa-arvon ja korkeakoulutuksen saavutettavuuden näkökulmasta selkeästi paras lähtökohta opiskelijavalinnoille" (OKM 2016: 37,9.)

Kuva ylioppilastutkinnosta neutraalina valintaperusteena syntyy tekstistä tunnistettavien hiljaisuuksien kautta. Työryhmä ei missään vaiheessa pohdi eri-ikäisinä ja eri aikoina suoritettujen ylioppilaskokeiden asemaa valinnoissa. Ylioppilastutkinnon arvosanan korottamisesta puhutaan samoin ongelmattomana asiana, vaikka se tarkoittaa hyvin erilaista ponnistusta sen mukaan, miten kauan oman tutkinnon suorittamisesta on. Työryhmä ei ota aikuisten asemaa millään tavalla huomioon. Sen sijaan se ilmaisee huolensa nuorimmista hakijoista, jotka ovat suorittaneet tutkintonsa digitaalisesti ja joille paperilla toteutettava pääsykoe olisi ongelmallinen. "Se asettaa opiskelijat hyvin erilaiseen asemaan kuin mihin he ovat tottuneet lukiossa ja mihin lukion opetussuunnitelma on heitä valmistanut." (OKM 2016: 37, 40.)

Työryhmä ei ota kantaa siihen, että ylioppilaskokeen uusiminen asettaa eriarvoiseen asemaan ne, jotka eivät aikanaan ole suorittaneet sitä digitaalisesti.
Paljastavaa on lisäksi tapa, jolla dokumentissa puhutaan motivaatiosta ja soveltuvuudesta. Motivaation yhteydessä puhutaan avoimesti nuorista korkeakoulutukseen hakijoista. "Yhtenä keskeisenä hyvän järjestelmän piirteenä voidaankin pitää sitä, että jokainen nuori voi hakea itseään eniten motivoivaan koulutukseen." (OKM 2016: 37, 47.) Aikuisten mahdollisista motiiveista tai opiskelemaan hakeutumisen syistä ei dokumentissa puhuta ollenkaan.

"Ammattialakohtaisen soveltuvuuden sijaan soveltuvuuden arvioinnin tulisi keskittyä opiskelijavalinnoissa soveltuvuudesta alan opintoihin eli siihen, miten hyvin opiskelija tulee suoriutumaan ao. opinnoissa, joihin hän on hakeutumassa." (OKM 2016: 37, 46.)

Soveltuvuudesta puhutaan asiana, joka kehittyy opintojen aikana (OKM 2016: 37,46). Sen mahdollinen kehittyminen työelämässä sivuutetaan täysin, joten aikuisen elämän- ja työkokemusta ei tässä yhteydessä huomioida valintoihin vaikuttavana tekijänä.

\section{TOISIA MAHDOLLISUUKSIA?}

Valintakriteereiden muutosten osana politiikkadokumentteihin on kirjattu niin sanottua toista mahdollisuutta koskevia toteamuksia. Puhe toisten mahdollisuuksien tarjoamisesta näyttäytyy kuitenkin vain eräänlaisena varautumisena mahdolliseen kritiikkiin (Jokinen 1999, 154-155).

”Raskas pääsykoejärjestelmä on ongelmallinen erityisesti lukion tai ammatillisen toisen asteen koulutuksen päättävien kannalta. Valintaperusteita tulisi uudistaa erityisesti tämän suuren hakijajoukon kannalta paremmiksi, unohtamatta hakeutumismahdollisuuksia muissa elämäntilanteissa." (OKM 2016: 37, 33.)

"Muissa elämäntilanteissa olevat" mainitaan lähinnä sivulauseessa. Valmiina valintoihin -mietinnössä (OKM 2016: 37) toisena mahdollisuutena mainitaan ylioppilastutkinnon uusiminen. Avoimen väylä vilahtaa tekstissä, mutta aihetta ei käsitellä sen enempää, vaan todetaan, että mahdollisuuksia on kehitetty, eikä tulevista kehittämistarpeista puhuta. 
KYSYMYKSET TOISISTA

\section{MAHDOLLISUUKSISTA}

\section{KEHYSTET ̈̈̈̈N NIVELVAIHEEN}

ONGELMILLA.

\begin{abstract}
"Ns. 'toinen mahdollisuus' osaamisen näyttämiseen tulisi työryhmän näkemyksen mukaan järjestää ensisijaisesti ylioppilastutkinnon kokeiden uusimisen kautta, koska se tarjoaa tasa-arvoisen mahdollisuuden osoittaa akateemista osaamista. [--] Tämän lisäksi tarvitaan myös muita mahdollisuuksia ja toissijaisia valintamenettelyjä hakeutumismahdollisuuksien varmistamiseksi erilaisissa elämäntilanteissa oleville. Viime aikoina korkeakoulut ovat kehittäneet perinteistä avoimen väylää lyhyempiä kurssien suorittamiseen perustuvia reittejä opintoihin.” (OKM 2016: 37, 65.)
\end{abstract}

Valmiina valintoihin II (OKM 2017: 25) sen sijaan jo tehtävänantonsa puolesta ottaa kantaa erilaisiin koulutuspolkuihin, olihan sen tehtävänä pohtia nimenomaan ammatillisen tutkinnon suorittaneiden hakeutumista korkeakouluun. Raportin keskeisiä ehdotuksia ovat muun muassa, että todistusvalintaa ammatilliselta toiselta asteelta tulisi kehittää erityisesti soveltuvan alan korkeakoulutukseen ja että todistusvalinnan lisäksi hakijoille tulisi olla väylä, jossa on mahdollista näyttää omaa osaamista ja kyvykkyyttä ja tulla siten valituksi korkeakouluun.

Aikuisuus ei kuitenkaan ollut tämänkään työryhmän ehdotuksissa juurikaan esillä. Kysymykset toisista mahdollisuuksista kehystetään nimenomaan nivelvaiheen ongelmilla. Raportin ehdotukset tähtäävät nuorten korkeakoulutukseen pääsyn nopeuttamiseen: "ettei ammatilliseen tutkintoon valmistuneille tule tarpeettomia taukoja jatko-opintoihin siirtymiseen” (OKM 2017:25, 102).

Ratkaisuja nopeammaksi siirtymiseksi toiselta asteelta korkea-asteelle suositetaan etsittäväksi myös toisen asteen oppilaitosten ja korkeakoulujen välisten yhteistyön muotojen kautta. Avoimen yliopiston väylää ja ammattikorkeakoulujen polkuopintoja vain sivutaan ja niitä koskevat toimenpide-ehdotukset koskevat ainoastaan yhteistyömallien kehittämistä aiempaa laajemmiksi ja systemaattisemmiksi. (OKM 2017: 25, 100-101.)

Raportissa kylläkin tunnistetaan aikuisten yhä suurempi osuus ei-ylioppilastaustaisissa hakijoissa: "Ammatillisen tutkinnon suorittaneiden osalta koulutuspolku, jossa ammatillisen tutkinnon suorittamisen jälkeen siirrytään työelämään, on merkittävä, mikä näkyy myös ikärakenteessa." (OKM 2017: 25, 30). Tekstissä todetaan lisäksi, että tätä polkua tulisi kehittää:

"Koulutuspolku, jossa ammatillisen tutkinnon jälkeen siirrytään työelämään, ja myöhemmin erityisesti ammattikorkeakoulututkintoon johtavaan koulutukseen, on merkittävä ja sitä tulisi ylläpitää ja kehittää." (OKM 2017: 25, 97.)

Aikuisuus tai aikuiset hakijat näkyvät tekstissä vain mainintoina, kuten ylipäätään toisten mahdollisuuksien tarjoamista koskevat kysymykset. Esimerkiksi erillisväylien kehittäminen ja laajentaminen, yleisiä valmiuksia mittaavien päs̈skokeiden kehittäminen ja työkokemusta tai ammatillista osaamista hyödyntävien valintatapojen kehittäminen tuodaan esiin ainoastaan spekulatiivisina vaihtoehtoina. Toisin sanoen teemaan liittyvää konkreettista politiikan toimenpidettä ei uudistuksesta pystytä tunnistamaan.

\section{POHDINTA}

Opiskelijavalintauudistuksen koulutuspoliittiseksi ongelmaksi on määrittynyt nimenomaan hidas ja sujumaton toisen ja kolmannen asteen välinen nivelvaihe. Siitä puhuttaessa ongelma kehystyy nuoria koskevaksi kysymykseksi. Analyysimme osoittaa, että opiskelijavalintapolitiikka on 2010-luvun reformin myötä kaventanut tyypillisen opiskelijan kuvaa. Oletettu opiskelija on nuori ylioppilas, joka hakee opiskelupaikkaa heti lukion jälkeen ja aloittaa opinnot siinä koulutuksessa, johon hänet valitaan. Samalla aikuiset opiskelijat marginalisoidaan aiempaa selvemmin omaan erityiseen asemaansa, josta käsin tutkintokoulutus ei näyttäydy oikeutettuna vaihtoehtona. 


\section{TUTKINTOKOULUTUKSEN}

EI EDES TOIVOTA OLEVAN

\section{AIKUISILLE YHT $\ddot{A}$}

\section{SAAVUTETTAVAA KUIN}

NUORILLE.

Opiskelijavalintauudistuksesta tunnistamamme kolme keskeistä toimea osallistuvat kukin aikuisen opiskelijan marginaalisen aseman rakentamiseen. Ensinnäkin valtakunnallisen hakujärjestelmän luominen näyttäytyy järjestelmän rationalisoinnin välineenä ja mahdollistaa aikuisten ohjaamisen järjestelmässä omille valintareiteilleen ja muuhun kuin tutkintokoulutukseen.

Toiseksi hakijoiden kiintiöinnit rakentavat käsitystä siitä, millaisia erilaisia hakijoita korkeakoulutukseen voi olla pyrkimässä. Kategorisointi on tehokas retorinen keino (Jokinen 1999, 129-130), sillä esitetty ryhmittely näyttäytyy kattavana kuvauksena siitä, millaisia hakijat ovat. Aikuisuus suljetaan ulos ensikertalaisten ja siirtyjien kategorioista, jolloin se kuvaa ainoastaan tutkinnon suorittaneiden ryhmään kuuluvia. Kategorisoinnin myötä aikuisena tutkintokoulutukseen hakevat määrittyivät oletetusti tutkinnon jo suorittaneiksi, jolloin heillä ei ole legitiimiä asemaa tutkinto-opiskelijana. Heitä pyritään ohjaamaan korkeakoulutuksen aikuiskoulutusmuotoihin ja maksullisille täydennyskoulutuskursseille.

Hakujärjestelmä ja kiintiöinnit ohjaavat näin yhdessä aikuisia ennen kaikkea tutkintokoulutuksen ulkopuolisiin koulutuksiin. Koulutuspoliittisissa dokumenteissa on 2000-luvun alusta lähtien ollut nähtävissä trendi, jossa aikuisten asema ja legitimiteetti tutkinto-opiskelijoina on kyseenalaistettu aiempaa vahvemmin (Haltia 2012). Analyysimme perusteella se on opiskelijavalintauudistuksessa vahvistunut entisestään. Tutkintokoulutuksen ei edes toivota olevan aikuisille yhtä saavutettavaa kuin nuorille (ks. McCowan 2016).

Kolmas toimenpide, opiskelijavalintakriteereiden muutos, työntää osaltaan aikuisia marginaaliin.
Ylioppilastutkinto näyttäytyy neutraalina, standardoituna ja luotettavana mittarina, jonka perusteella opiskelijat voidaan valita oikeudenmukaisesti, tehokkaasti ja laadukkaasti. Todistusvalinnan paremmuutta argumentoidaan politiikkateksteissä menettelyn tasa-arvon (Jacobs 2013) näkökulmasta, jolloin hakijoiden samanlainen kohtelu asettuu keskeisimmäksi valinnan oikeudenmukaisuuden kriteeriksi. Pääsykoetta on meillä pidetty monesti mittarina, jossa kaikki samaan koulutukseen hakevat asetetaan kilpailemaan opiskelupaikoista oikeudenmukaisella tavalla ja jonka vastakohtana esimerkiksi avoimen yliopiston väylän olemassaolon oikeutusta on pyritty kyseenalaistamaan (Haltia 2015). Uudistuksen politiikkadokumentit asettavat pääsykokeen ja ylioppilastutkinnon retorisesti toisilleen vastakkaisiksi vaihtoehdoiksi ja argumentoivat nimenomaan ylioppilastutkinnon puolesta.

Politiikkatekstit vaikenevat siitä, että ylioppilastutkinto rajaa osan hakijoista pois. Samalla niissä kuitenkin todetaan kuin ohimennen, että muidenkin hakijaryhmien mahdollisuuksista on huolehdittava. Kun ylioppilastutkinnon luotettavuutta ja erinomaisuutta valintakriteerinä painotetaan voimakkaasti, muut valintavat näyttäytyvät toissijaisina reitteinä, jotka eivät täytä ensisijaista menettelyn tasa-arvoisuuden kriteeriä (Jacobs 2013). Niitä pidetään sattumanvaraisempina ja epäluotettavampina (ks. Pitman 2016, 1213). Puhe toisista mahdollisuuksista on näin itse asiassa oikeuttamassa uudistusten varsinaista pääsisältöä, nuorten lukiosta valmistuneiden hakijoiden sisäänpääsyn parantamista korkeakoulujen todistusvalinnoissa. Vaihtoehtoisissakin reiteissä aikuisuus on häivytetty, ja puhutaan lähinnä nopeasta siirtymästä korkeakoulutukseen ammatillisen tutkinnon suorittamisen jälkeen.

Lesley Jacobsin (2013) mukaan menettelyn, taustan ja panosten reiluus ovat ulottuvuuksia, jotka kaikki otetaan ihannetapauksessa samanaikaisesti huomioon. Menettelyn tasa-arvon kysymystä on suomalaisessa järjestelmässä pidetty vahvana ja meritokraattisia valintakriteereitä keskeisinä oikeudenmukaisuuden edellytyksinä. Taustan mukaiseen reiluuteen taas on pyritty vaikuttamaan muun muassa tutkintokoulutuksen maksuttomuudella ja laajasti määritetyllä yleisellä korkeakoulukelpoisuudella. Panosten reiluus on näkynyt 
siinä, että uusia valintoja on voinut tehdä, ja että erilaiset siirtymät elämänuralla, myös tutkintokoulutukseen hakeutumalla, ovat olleet mahdollisia.

2010-luvun lopussa herännyt vilkas keskustelu aikuisten oppimismahdollisuuksien ympärillä on nostanut aikuiset taas koulutuspolitiikan ytimeen. Vuoden 2018 aikana politiikkateksteihin ilmaantuneesta jatkuvan oppimisen käsitteestä on tullut mantra, jota on eri foorumeilla alettu innokkaasti toistaa ja joka on saamassa korkeakoulujen uusissa rahoitusmalleissa aiempaa suuremman painoarvon (OKM 2019).

'Jatkuva oppiminen' on määritelty koulutuspoliittisessa diskurssissa tarkoittamaan ennen kaikkea työelämässä olevien henkilöiden osaamisen jatkuvaa päivittämistä (ks. OKM 2018: 8), ja se liittyy myös kansainvälisesti meneillään olevaan aikuiskoulutuksen markkinoistumis- ja kaupallistumiskehitykseen (ks. esim. Fejes \& Olesen 2016). Sillä ei ainakaan ensisijaisesti tavoitella sitä, että tutkintoon johtavien korkeakoulupaikkojen saatavuutta parannettaisiin (vrt. McCowan), ja aikuisille luotaisiin lisää mahdollisuuksia sisäänpääsyyn.

Maksuttoman tutkintokoulutuksen avoimuutta aikuisille voidaan kuitenkin tarkastella koulutus- järjestelmämme tasa-arvoisuuden yhtenä mittarina. Huoli nuorten opiskelupaikkojen saannista ja sujuvasta siirtymästä on oikeutettu, ja kysymyksestä tulee ongelmallinen juuri siitä syystä, että opiskelupaikkoja on rajallisesti.

Kilpailun nollasummapelin luonteesta johtuu, että jos jokin ryhmä on etulyöntiasemassa, muut ryhmät vastaavasti kärsivät (Brighouse \& Swift 2006). On kuitenkin lyhytnäköistä ajatella, että aikuisten ja nuorten intressit olisivat toisilleen täysin vastakkaiset tai että aikuisten mahdollisuudet olisivat yksiselitteisesti nuorilta pois. Kysymystä kilpailusta voidaan katsoa yksilöiden koko elämänkulun mitalta, jolloin asiaa voidaan tarkastella panosten tasa-arvon näkökulmasta (Jacobs 2013).

Juuri se, että yhteiskunnassa on opiskelumahdollisuuksia aikuisille, luo näköaloja myös nuorille. Koulutusjärjestelmän kokonaisuus luo mielikuvia siitä, miten märäävä tässä hetkessä tehtävä ratkaisu on, ja miten yhteiskunta antaa mahdollisuuden elämän eri vaiheissa tehdä elämää suuntaavia valintoja. Jos nuorilla on näkemys siitä, että heidän valintansa eivät välttämättä ole lopullisia, se voi helpottaa usein vaikeiksi ja stressaaviksi koettuja valintoja toisen asteen opintojen päättyessä.

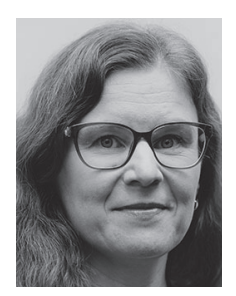

NINA HALTIA

$\mathrm{KT}$, tutkijatohtori

kasvatustieteiden laitos

Turun yliopisto

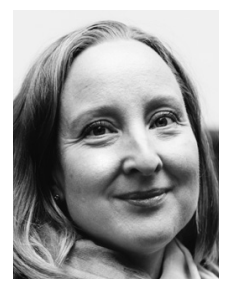

ULPUKKA ISOPAHKALA-BOURET

$K T$, dosentti, apulaisprofessori

kasvatustieteiden laitos

Turun yliopisto

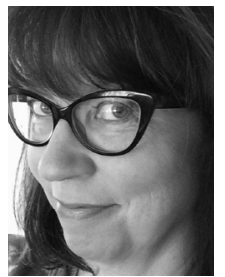

ANNUKKA JAUHIAINEN

$\mathrm{KT}$, lehtori

kasvatustieteiden laitos

Turun yliopisto

Kiitämme tohtorikoulutettava FM, KM Marja Peuraa, joka tutkimusharjoittelunsa osana syksyllä 2016 avusti osassa aineistojen ensimmäisiä analyyseja. 
Ahola, S. \& Spoof, J. (2018). Mikä olisi paras tapa valita korkeakouluopiskelijat? - opiskelijavalintojen uudistamiseen liittyvän keskustelun jakolinjat. Tiedepolitiikka 43(3), 7-21.

Ahola, S. (2004). Yhteishausta yhteisvalintaan. Yliopistojen opiskelijavalinnan kehittäminen. Opetusministeriön työryhmämuistioita ja selvityksiä 2004:9. Helsinki: Opetusministeriö.

Allan, E. J. (2012). Policy Discourses, Gender, and Education. Constructing Women's Status. New York: Routledge.

Antikainen, A. (2006). In search of the Nordic model in education. Scandinavian Journal of Educational Research 50(3), 229-243.

Aro, M. (2014). Koulutusinflaatio. Koulutusekspansio ja koulutuksen arvo Suomessa 1970-2008. Turun yliopiston julkaisuja 376.

Bacchi, C. (2000). Policy as Discourse: What does it mean? Where does it get us? Discourse: Studies in the Cultural Politics of Education 21(1), 45-57.

Ball, S. (1994). Education reform. A critical and poststructural approach. Buckingham: Open University Press.

Brighouse, H. \& Swift, A. (2006). Equality, Priority, and Positional Goods. Ethics 116(3), 471-497.

Chouliaraki, L. \& Fairclough, N. (1999). Discourse in late modernity: rethinking critical discourse analysis. Edinburgh: Edinburgh University Press.

Fejes, A. \& Salling Olesen, H. (2016) Editorial: Marketization and commodification of adult education. European Journal for Research on the Education and Learning of Adults 7(2), 146-150. http://www.rela. ep.liu.se/issues/10.3384_rela.2000-7426.201672/01/ rela_v7i2_editorial.pdf.

Haltia, N. (2012). Vähäistä hyväksilukua ja ketjutettuja tutkintoja: Aikuinen yliopisto-opiskelija 2000-luvun koulutuspoliittisessa diskurssissa. Kasvatus 43(5), 476-487.

Haltia, N., Jauhiainen, A. \& Isopahkala-Bouret, A. (2017). Ei-ylioppilastaustaiset korkeakouluopiskelijat. Eurostudent VI -tutkimuksen artikkelisarja. Opetus- ja kulttuuriministeriön julkaisuja 2017:28.

Haltia, N., Jauhiainen, A. \& Isopahkala-Bouret, U. (2018). Epätavallista reittiä yliopistoon - ilman ylioppilastutkintoa yliopistoon hakeneiden taustat ja sisäänpääsy koulutukseen. Teoksessa R. Rinne, N. Haltia, S. Lempinen \& T. Kaunisto. (toim.) Eriarvoistuva maailma - tasa-arvoistava koulu? Suomen kasvatustieteellinen seura: Kasvatusalan julkaisuja 78, 223-244.

Haltia, N. (2015). Avoimen yliopiston tutkintoväylä koulutuspoliittisessa keskustelussa. Aikuiskasvatus 35 (4), 254-265.
HE 244/2014/vp. Hallituksen esitys eduskunnalle laeiksi yliopistolain ja ammattikorkeakoululain muuttamisesta.

HE 44/2012/vp. Hallituksen esitys eduskunnalle yliopistolain 36 ja 38 §:n, ammattikorkeakoululain sekä opiskelijavalintarekisteristä ja ylioppilastutkintorekisteristä annetun lain muuttamisesta.

Isopahkala-Bouret, U., Börjesson, M., Beach, D., Haltia, N., Jónasson, J. T., Jauhiainen, A., Jauhiainen, A., Kosunen, S., Nori, H. \& Vabø, A. (2018). Access and Stratification in Nordic Higher Education. A review of cross-cutting research themes and issues. Education Inquiry 9 (1), 142-154.

Jacobs, L. A. (2013). A vision of equal opportunity in postsecondary education. Teoksessa H.-M. Meyer, E. P. St. John, M. Chankseliani and L. Uribe (toim.) Fairness in Access to Higher Education in a Global Perspective: Reconciling Excellence, Efficiency, and Justice. Boston: Sense Publishers, 41-56.

Jokinen, A. (1999). Vakuuttelevan ja suostuttelevan retoriikan analysoiminen. Teoksessa A. Jokinen, K. Juhila \& E. Suoninen (toim.) Diskurssianalyysi liikkeessä. Tampere: Vastapaino, 126-159.

Kettunen, H., Pulkkinen, S. \& Saari, J. (2013). Ammattikorkeakoulujen aikuisopiskelijat. Helsinki: Opiskelun ja koulutuksen tutkimussäätiö Otus.

Kivinen, O., Hedman, J. and Kaipainen, P. (2012). Koulutusmahdollisuuksien yhdenvertaisuus Suomessa. Eriarvoisuuden uudet ja vanhat muodot. Yhteiskuntapolitiikka 77 (5), 579-586.

Koski, L. \& Moore, E. (2001). Näkökulmia aikuisuuteen ja aikuiskasvatukseen. Aikuiskasvatus 21(1), 4-13.

Kosunen, S., Haltia, N. \& Jokila, S. (2015). Valmennuskurssit ja mahdollisuuksien tasa-arvo yliopistokoulutukseen hakeutumisessa. Kasvatus 46(4), 334-348.

Kouvo, A. (2014). Luottamuksen lähteet. Vertaileva tutkimus yleistynyttä luottamusta synnyttävistä mekanismeista. Turun yliopiston julkaisuja C 381 .

McCowan, T. (2016). Three dimensions of equity of access to higher education. Compare 46(4), 645-665.

Moore, E. (2011). Aikuiset korkeakoulutuksessa. Teoksessa R. Rinne \& A. Jauhiainen (toim.) Aikuiskasvatus ja demokratian haaste. Helsinki: Kansanvalistusseura ja Aikuiskasvatuksen tutkimusseura, 182-197.

Nori, H. (2011). Keille yliopiston portit avautuvat? Tutkimus suomalaisiin yliopistoihin ja eri tieteenaloille valikoitumisesta 2000-luvun alussa. Turun yliopiston julkaisuja C 309.

Ojala, K. \& Haltia, N. (2018). Ammatillista osaamista ja verkostoitumista - Aikuisopiskelijoiden kokemat hyödyt ammattikorkeakoulutuksessa. Teoksessa A. 
Jauhiainen, J. Kivirauma \& H. Kinnari (toim.) Koulutus hallinnassa. Juhlakirja professori Heikki Silvennoisen täyttäessä 60 vuotta 23.2.2018. Turun yliopiston kasvatustieteiden tiedekunnan julkaisuja A:216, 251-277.

OKM 2012. Koulutus ja tutkimus vuosina 2011-2016. Kehittämissuunnitelma. Opetus- ja kulttuuriministeriön julkaisuja 2012:1.

OKM 2017:25. Valmiina valintoihin II. Ammatillisesta koulutuksesta korkeakouluun.

OKM 2018:8. Työn murros ja elinikäinen oppiminen. Elinikäisen oppimisen kehittämistarpeita selvittävän työryhmän raportti. Opetus- ja kulttuuriministeriön julkaisuja.

OKM 2019. Korkeakouluille uusi rahoitusmalli. https:// minedu.fi/artikkeli/-/asset_publisher/korkeakouluilleuusi-rahoitusmalli (18.1.2019).

Olkinuora, E. Rinne, R. Mäkinen, J. Järvinen, T. \& Jauhiainen, A. (2008). Promises and risks of the learning society: the meanings of lifelong learning for three Finnish generations. Studies in the Education of Adults 40(1), 40-61.

OPM 2010:11. Ei paikoillanne, vaan valmiit hep! Koulutukseen siirtymistä ja tutkinnon suorittamista pohtineen työryhmän mietintö.
Pitman, T. (2016). Understanding 'fairness' in student selection: are there differences and does it make a difference anyway? Studies in Higher Education 41(7), 1 203-1 216.

Rinne, R., Haltia, N., Nori, H. \& Jauhiainen, A. (2008). Yliopiston porteilla. Aikuiset ja nuoret sisäänpäässeet 2000-Iuvun alun Suomessa. Suomen kasvatustieteellinen seura: Kasvatusalan julkaisuja 36.

Siivonen, P. \& Isopahkala-Bouret, U. (2016). Adult graduates' negotiations of age(ing) and employability. Journal of Education and Work 29(3), 352-372.

Tervasmäki, T. \& Tomperi, T. (2018). Koulutuspolitiikan arvovalinnat ja suunta satavuotisessa Suomessa. niin \& näin 25(2), 164-200.

Ulriksen, L. (2009). The implied student. Studies in Higher Education 34(5), 517-532.

Valtioneuvosto (2011). Pääministeri Jyrki Kataisen hallituksen ohjelma 22.6.2011.

Valtioneuvosto (2015). Ratkaisujen Suomi. Pääministeri Juha Sipilän hallituksen strateginen ohjelma 29.5.2015.

Valtioneuvosto 2016:2. Toimintasuunnitelma strategisen hallitusohjelman kärkihankkeiden ja reformien toimeenpanemiseksi 2015-2019. OKM 2016:37. Valmiina valintoihin. Ylioppilastutkinnon parempi hyödyntäminen korkeakoulujen opiskelijavalinnoissa. 